\title{
Development of 王老先生 Wánglăoxiānsheng Pop-Up Tale Book for Kindergarten Children Aged 4-5 Year Learning Mandarin Vocabulary
}

\author{
Ariesa Restianti Binawati \\ Universitas Negeri Surabaya \\ Surabaya, Indonesia \\ ariesab@mhs.unesa.ac.id
}

\author{
Maria Mintowati \\ Universitas Negeri Surabaya \\ Surabaya, Indonesia \\ mintowati@unesa.ac.id
}

\begin{abstract}
This research is development research with aim to development 王老先生 pop-up tale books. The result research used to learn Mandarin vocabulary for kindergarten children aged 4-5 years. Development model used ADDIE (Analysis, Design, Development, Implementation, and Evaluation). The product tested for students of TK A1 TK "Negeri Kuncup Bunga". Result of research showing that 1) development pop-up tale book process have done followed by ADDIE steps but pop-up tale book has not been developed massively; 2) pop-up tale book quality can describe with (1) material validity aspect is $98 \%$ and media validity aspect is 84\%; (2) effectiveness aspect obtained test result with ratio $t_{\text {score }}$ and $t_{\text {significant }}$ yakni $t_{\text {score }}<t_{\text {significant }}=0,85<4,35$ and observation of teacher-student learning activity can be prove percentage $90,5 \%$ (mean is pop-up tale books effective for teaching Mandarin vocabulary); (3) practicability aspect got from interview of student response, result is $66,67 \%$ knowing all of animal in tale books, $33,33 \%$ said that pop-up tale books is great, and $26,67 \%$ want to take pop-up tale books in home.
\end{abstract}

Keywords-tale, pop-up, vocabulary learning, early children education

\section{INTRODUCTION}

Education is an activity which pursued for develop human ability and human skills. There are many kind education and divided into informal, formal, and non formal. In formal education, there are early children education, basic education, middle education, and high education. Education aim to develop attitude, cognitive, and psychomotor. Achievement of these three domains, one of them through teaching foreign language, especially Mandarin and language ability. All language teaching concept has done used in early children (preschool children and basic elementary student) for develop children language [1].

Now Mandarin teaching very important [2]. He said that China's people is $20 \%$ worlds people. Mandarin language is a one of difficult language for learned because Mandarin has four ability to learn which writing, reading, speaking, and listening.

Mandarin learning has expanded to early children education but there is a problem of the limited teaching materials for kindergarten children aged 4-5 years learn of Mandarin vocabulary. That is basic of this research which develop pop-up tale book for Mandarin vocabulary learning aim to Mandarin vocabulary easy learn and attract kindergarten children aged 4-5 years Mandarin learning motivation.

Based on that explanation, research development 王老先 生 Wáng Lăo Xiānsheng pop-up tale books for Mandarin vocabulary learning of kindergarten children aged 4-5 years. The excess of the pop-up tale book is give learning Mandarin vocabulary so easy and attractive aim to describe development pop-up tale book process and pop-up tale book quality can be prove with three aspects, validity, effectiveness, also practicability.

\section{RESEARCH METHODS}

This research used development ADDIE model (Analysis, Design, Development, Implementation, and Evaluation). This research has not developed massively because of limited manpower. Validity of pop-up tale book did in Faculty Language and Arts, State University of Surabaya, that pop-up tale books tested to student TK A1 of TK "Negeri Kuncup Bunga” in February-March 2018.

The research product are pop-up tale book for Mandarin vocabulary learning of kindergarten children aged 4-5 years. The target of trials is students TK A1 TK "Negeri Kuncup Bunga" used samples aims because students did not focused on learning and active.

Research design used pre-experimental with one-group pretest-posttest method did in implementation step. Data collected through method test and observation learning activity as measure effectiveness, interview for measure practicaly and also necessary analysis, and validate materials and media. Afterward data was analyzed use attitude measure scale to confirmed likert scale have done modified, while test result processed with t-test. 


\section{RESULT AND DISCUSSION}

Research development result include development popup tale book process and pop-up tale book as follows.

\section{A. Research result}

\section{Development pop-up tale book process}

Development process begin with analysis steps aim to analyzed necessaries to teachers TK A TK "Negeri Kuncup Bunga".

Followed by design step has prepared before, then adjusted with necessaries analysis result. That design is research instrument design, material design, also pop-up tale book design. Next step was developed design and did validate in Faculty Language and Arts State University of Surabaya.

Research result then implemented in Mandarin learning on the students TK A1 TK "Negeri Kuncup Bunga", also there are pretest-posttest and observation of learning activity.

Evaluation has been did in development step and implementation step which validate, test, and observation learning activity.

\section{a. Pop-up tale book quality}

Pop-up tale book quality can be prove through three aspects which validity, effectiveness and praticaly. The result of three aspect is:

\section{1) Validity Aspect}

Validity aspect through with material validity and media validity in Faculty of Language and Arts State University of Surabaya. Material validity judgment by 刘㻦 Liú yǔ. These result of material validity is:

TABLE 1. JUDGMENT OF MATERIAL VALIDITY

\begin{tabular}{|c|c|c|c|c|c|c|c|}
\hline \multirow{2}{*}{ No. } & \multirow{2}{*}{$\begin{array}{c}\text { Judgment } \\
\text { Aspect }\end{array}$} & \multirow{2}{*}{ Point } & \multicolumn{5}{|c|}{ Judgment Scale } \\
\hline & & & 1 & 2 & 3 & 4 & 5 \\
\hline \multirow{3}{*}{1.} & \multirow{3}{*}{$\begin{array}{l}\text { Compatibility of } \\
\text { language aspect }\end{array}$} & $\begin{array}{l}\text { Vocabulary used } \\
\text { simple }\end{array}$ & & & & & $\sqrt{ }$ \\
\hline & & Sentence used simple & & & & & $\sqrt{ }$ \\
\hline & & Grammar used simple & & & & $\sqrt{ }$ & \\
\hline \multirow{2}{*}{2.} & \multirow{2}{*}{$\begin{array}{l}\text { Technic of } \\
\text { presentation tale }\end{array}$} & $\begin{array}{l}\text { Tale is presented } \\
\text { interesting }\end{array}$ & & & & & $\sqrt{ }$ \\
\hline & & $\begin{array}{l}\text { Tale is presented } \\
\text { attractive }\end{array}$ & & & & & $\sqrt{ }$ \\
\hline \multirow{3}{*}{3.} & \multirow{3}{*}{$\begin{array}{l}\text { Compatibility of } \\
\text { lesson }\end{array}$} & $\begin{array}{l}\text { Difficulties } \\
\text { appropriate with } \\
\text { thought kindergarten } \\
\text { children age } 4-5 \text { years }\end{array}$ & & & & & $\sqrt{ }$ \\
\hline & & $\begin{array}{l}\text { Illustration used } \\
\text { interesting }\end{array}$ & & & & & $\sqrt{ }$ \\
\hline & & $\begin{array}{l}\text { Lesson can be } \\
\text { motivation learning } \\
\text { for kindergarten } \\
\text { children age } 4-5 \text { years }\end{array}$ & & & & & $\sqrt{ }$ \\
\hline \multirow[t]{2}{*}{4.} & \multirow[t]{2}{*}{ Look of book } & $\begin{array}{l}\text { Illustration used } \\
\text { interesting and } \\
\text { attractive }\end{array}$ & & & & & $\sqrt{ }$ \\
\hline & & Book look simple & & & & & $\sqrt{ }$ \\
\hline
\end{tabular}

Material validity consist of four aspect about material and pop-up tale book looking obtained percentage is $98 \%$. Media validity judgment by M.Ariffudin Islam, S.Sn., M.Sn. These result of media validity is:

\section{TABLE 2. JUDGMENT OF MEDIA VALIDITY}

\begin{tabular}{|c|c|c|}
\hline No. & Judgment Aspect & Judgment Scale \\
\hline & & \\
\hline 1. & Font used clear & \\
\hline 2. & Language used short, compact, and clear & \\
\hline 3. & $\begin{array}{l}\text { Lesson according to kindergarten } \\
\text { children aged } 4-5 \text { years }\end{array}$ & \\
\hline 4. & $\begin{array}{l}\text { Illustration compatible with theme } \\
\text { (animal) }\end{array}$ & \\
\hline 5. & Illustration are interesting and not scary & \\
\hline 6. & $\begin{array}{l}\text { Illustration is attractive according to } \\
\text { characteristic kindergarten children age } \\
4-5 \text { years }\end{array}$ & \\
\hline 7. & Color balance & \\
\hline 8. & Illustration balance & \\
\hline 9. & Material present according illustration & \\
\hline 10. & $\begin{array}{l}\text { Ideal of illustration layout with material } \\
\text { is not bewilder }\end{array}$ & \\
\hline
\end{tabular}

Media validity consist of two aspect which material and pop-up tale book obtained percentage $84 \%$

\section{2) Effectiveness aspect}

Effectiveness aspect got from test and observation of learning activity in TK A1 TK "Negeri Kuncup Bunga". Observation of learning activity judgment by Wifi Nadhifa, S.Pd, teacher of TK A1. These result of pretest-posttest is:

TABLE 3. RESULT OF PRETEST-POSTTEST

\begin{tabular}{|c|c|c|c|c|c|c|}
\hline No. & Name & Pretest & Posttest & D & $\begin{array}{l}\text { Xd } \\
(\mathbf{d}- \\
\text { Md) }\end{array}$ & $X^{2} d$ \\
\hline 1. & $\mathrm{KV}$ & 100 & 100 & & & \\
\hline 2. & MRN & Sakit & 65 & & & \\
\hline 3. & ZNB & Sakit & 100 & & & \\
\hline 4. & $\overline{\text { ARL }}$ & 76 & 100 & 24 & 13 & 544 \\
\hline 5. & $\overline{\mathrm{CLN}}$ & 100 & 100 & & & \\
\hline 6. & $\mathrm{ZK}$ & 41 & 65 & 24 & 13 & 544 \\
\hline 7. & ERLN & 60 & 90 & 30 & 19 & 850 \\
\hline 8. & DVN & Sakit & Sakit & & & \\
\hline 9. & ZL & 52 & 80 & 28 & 17 & 740 \\
\hline 10. & $\mathrm{CL}$ & 70 & 80 & 10 & -1 & 94 \\
\hline 11. & DSCH & 80 & 90 & 10 & -1 & 94 \\
\hline 12. & TTK & 60 & 70 & 10 & -1 & 94 \\
\hline 13. & NWG & 30 & 40 & 10 & -1 & 94 \\
\hline 14. & RZK & 13 & Sakit & & & \\
\hline 15. & KRSTBL & 90 & Sakit & & & \\
\hline 16. & KNTH & 80 & 100 & 20 & 9 & 378 \\
\hline 17. & FR & 64 & 80 & 16 & 5 & 242 \\
\hline 18. & $\mathrm{BM}$ & 30 & 45 & 15 & 4 & 213 \\
\hline \multirow{4}{*}{$\begin{array}{c}\boldsymbol{T} \\
\boldsymbol{O} \\
\boldsymbol{T} \\
\boldsymbol{A} \\
\boldsymbol{L}\end{array}$} & $\mathbf{N}$ & EPretest & $\sum$ Posttest & $\sum \mathbf{d}$ & & \\
\hline & 18 & 956 & 1215 & 197 & & \\
\hline & & $M p r$ & Мро & Md & & $\sum_{X^{2} d}$ \\
\hline & & 53,11 & 67,5 & 11 & & 3343 \\
\hline
\end{tabular}


From table present obtained increasing in result test is pretest rate 53,11 and posttest rate 67,5. Then data analyzed use t-test and obtained ratio result $t_{\text {score }}$ and $t_{\text {significant }}$ are $t_{\text {score }}$ $<\mathrm{t}_{\text {significant }}=0,85<4,35$.

These observation of learning activity result get through two observation which observation teacher activity and observation student activity is:

\section{1) Result of observation teacher activity}

Observation teacher activity has three aspects which pre learning :

TABLE 4. JUGDMENT TEACHER ACTIVITY

\begin{tabular}{|c|c|c|c|c|c|c|}
\hline \multirow{2}{*}{ No. } & \multirow{2}{*}{ Statement } & \multicolumn{5}{|c|}{ Judgment Scale } \\
\hline & & 1 & 2 & 3 & 4 & 5 \\
\hline \multicolumn{7}{|c|}{ Prelearning Aspect } \\
\hline 1. & $\begin{array}{l}\text { Capability of check readiness students } \\
\text { include say hello and lead pray }\end{array}$ & & & & $\sqrt{ }$ & \\
\hline 2. & Capability of explanation learning purpose & & & & & $\sqrt{ }$ \\
\hline 3. & Capability of dive motivation for students & & & & & $\sqrt{ }$ \\
\hline 4. & Capability to doing apersepsi activities & & & & $\sqrt{ }$ & \\
\hline \multicolumn{7}{|c|}{ Learning Contents Aspect } \\
\hline 1. & $\begin{array}{l}\text { Skill of teacher process class became more } \\
\text { fun }\end{array}$ & & & & $\sqrt{ }$ & \\
\hline 2. & $\begin{array}{l}\text { Do learning according with learning } \\
\text { purpose will be achieve }\end{array}$ & & & & & $\sqrt{ }$ \\
\hline 3. & Indicate to command learning material & & & & & $\sqrt{ }$ \\
\hline 4. & Story telling use pop-up tale book & & & & & $\sqrt{ }$ \\
\hline 5. & $\begin{array}{l}\text { Skill of use Mandarin in explanation } \\
\text { material Mandarin with good and right }\end{array}$ & & & & & $\sqrt{ }$ \\
\hline 6. & $\begin{array}{l}\text { Skill of using Bahasa when story telling } \\
\text { with effectiveness and communicative }\end{array}$ & & & & & $\sqrt{ }$ \\
\hline 7 & Use clear voice in story telling & & & & & $\sqrt{ }$ \\
\hline 8. & $\begin{array}{l}\text { Skill of time management in learning } \\
\text { activity }\end{array}$ & & & & $\sqrt{ }$ & \\
\hline 9. & Do learning continuously & & & & $\sqrt{ }$ & \\
\hline 10. & $\begin{array}{l}\text { Growing joy and enthusiasm students in } \\
\text { learning }\end{array}$ & & & & $\sqrt{ }$ & \\
\hline 11. & $\begin{array}{l}\text { Invite students for seeing and touching pop- } \\
\text { up tale book }\end{array}$ & & & & & $\sqrt{ }$ \\
\hline 12. & $\begin{array}{l}\text { Use teaching materials according with } \\
\text { students competence }\end{array}$ & & & & & $\sqrt{ }$ \\
\hline 13. & $\begin{array}{l}\text { Showing open minded for students } \\
\text { response }\end{array}$ & & & & & $\sqrt{ }$ \\
\hline \multicolumn{7}{|c|}{ Closing Learning Aspect } \\
\hline 1. & $\begin{array}{l}\text { Create summary that has been studied with } \\
\text { students }\end{array}$ & & & & $\sqrt{ }$ & \\
\hline 2. & Give sign for doing task & & & & $\sqrt{ }$ & \\
\hline
\end{tabular}

Data in there table analyzed with percentage technic and there result confirm on likert scale and percentage get $92 \%$.

\section{2) Observation of student activity result}

Quoad observation of student activity result can show through three aspect which learning atmosphere, student attitude and behavior, and students' ability, there are:
TABLE 5. OBSERVATION OF STUDENT ACTIVITY JUDGMENT

\begin{tabular}{|c|l|c|c|c|c|c|}
\hline \multirow{2}{*}{ No. } & \multicolumn{1}{|c|}{ Statement } & \multicolumn{3}{|c|}{ Judgment Scale } \\
\hline & & $\mathbf{1}$ & $\mathbf{2}$ & $\mathbf{3}$ & $\mathbf{4}$ & $\mathbf{5}$ \\
\hline 1. & $\begin{array}{l}\text { Students could be focused when teacher } \\
\text { telling story from pop-up tale book }\end{array}$ & & & & $\sqrt{ }$ & \\
\hline 2. & $\begin{array}{l}\text { Students attract for touch and hold pop-up } \\
\text { tale book }\end{array}$ & & & & $\sqrt{ }$ \\
\hline 3. & $\begin{array}{l}\text { Students look happier and not bored on } \\
\text { learning process in class }\end{array}$ & & & & $\sqrt{ }$ & \\
\hline 4. & Students doing task easily after learning & & & & $\sqrt{ }$ & \\
\hline 5. & $\begin{array}{l}\text { Tasks assigned by teacher make students } \\
\text { more understand }\end{array}$ & & & & $\sqrt{ }$ & \\
\hline 6. & $\begin{array}{l}\text { Learning atmosphere looks happy and } \\
\text { orderly }\end{array}$ & & & & $\sqrt{ }$ & \\
\hline 7. & $\begin{array}{l}\text { Students could share view pop-up tale } \\
\text { book }\end{array}$ & & & & & $\sqrt{ }$ \\
\hline 8. & $\begin{array}{l}\text { Students could understand Mandarin } \\
\text { vocabulary of animal }\end{array}$ & & & & $\sqrt{ }$ & \\
\hline 9. & $\begin{array}{l}\text { Students could be polite when learning } \\
\text { process }\end{array}$ & & & & $\sqrt{ }$ & \\
\hline 10. & $\begin{array}{l}\text { Students have responsibility on the result } \\
\text { tasks. }\end{array}$ & & & & $\sqrt{ }$ & \\
\hline
\end{tabular}

Data on the table analyzed with percentage technic and there result confirm on likert scale and percentage get $84 \%$

Then both of observation result calculated average with the result that $90,5 \%$ clarify observation result so effective for used on Mandarin vocabulary in kindergarten children age 4-5 years.

\section{3) Practicability aspect}

Practicability aspect get used interview method because kindergarten children age 4-5 years could not express his thought through writing. There interview students response result judgment with three aspect is learning, pop-up tale book fill, and students response with the result that $66,67 \%$ students know all of animal in story, furthermore $33,33 \%$ said that pop-up tale book so good and $26,67 \%$ students want to take pop-up tale book home.

\section{B. Discuss}

Research held on February-March 2018 through five steps that necessary analysis, design, development, implementation, and evaluation. Research produce pop-up tale book which include into type supporting book and fiction book [3]. Pop-up tale book themed animals as an auxiliary book 你好! nǐ hăo! Mandarin use for TK A Kidergarten children books on 农村动物 (nóngcūn dòngwù) material. Types of tale used personificarion tale [4] and puzzle model on three dimension [5].

On implementation step used on-group pretest-posttest method [6]. In this design given pretest and posttest for measure effectiveness aspect. That result is ratio result $t_{\text {score }}$ and $t_{\text {significant }}$ that $t_{\text {score }}<t_{\text {significant }}=0,85<4,35$. Research also doing observation teacher and student activity and percentage get $90,5 \%$. Researcher interview students for get students response and result that $66,67 \%$ as answer of animal question in story. Furthermore response that $33,33 \%$ said that pop-up tale book so good and $26,67 \%$ want to take pop-up tale book home. 
Evaluation also doing validate which material validation get percentage $98 \%$ and media validation get percentage $84 \%$. From that result could concluded that pop-up tale book is valid for used on Mandarin vocabulary learning.

\section{CONCLUSION}

The research conclusion is (1) development process have done but has not been develop massively because limited force and fund, (2) pop-up tale book quality revealed through aspect of material validation get $98 \%$ and media validation get 84\%; effectiveness aspects founded from result test with ratio $t_{\text {score }}$ and $t_{\text {significant }}$ that $t_{\text {score }}<t_{\text {significant }}=$ $0,85<4,35$, result of observation teacher and students learning activity get percentage that $90,5 \%$ meaning that pop-up tale book effective for use Mandarin vocabulary learning; practicability aspect get from student response interview with result that $66,67 \%$ for animal knowledge in story, $33,33 \%$ said that pop-up tale book so good and $26,67 \%$ want to take pop-up tale book home.

\section{REFERENCES}

[1] A. Sapto, China dan Pentingnya Bahasa Mandarin. Kompasiana (Beyond Blogging), 2010.

[2] A. Wicaksono, and A.S. Roza, Teori Pembelajaran Bahasa (Suatu Catatan Singkat). Yogyakarta: Penerbit Garudhawaca, 2016.

[3] Darmono, Perpustakaan Sekolah: Pendekatan Aspek Manajemen dan Tata Kerja. Jakarta: Grasindo, 2007.

[4] 方圆,《绩苹果写作与作文》, 济南: 山东教育出版社, 2009.

[5] N. Sudjana, Nana and R, Ahmad Media Pengajaran (Penggunaan dan Pembuatannya). Bandung: Sinar Baru Algensindo, 2002.

[6] M.A. Yusuf, Metode Penelitian Kuantitatif, Kualitatif, dan Penelitian Gabungan. Jakarta: Kencana, 2014. 